\title{
On the action of light on the electrical conductivity of the haloid salts of silver
}

\section{Svante Arrhenius}

To cite this article: Svante Arrhenius (1888) On the action of light on the electrical conductivity of the haloid salts of silver, Philosophical Magazine Series 5, 25:156, 451-452, DOI:

$10.1080 / 14786448808628212$

To link to this article: http://dx.doi.org/10.1080/14786448808628212

曲 Published online: 29 Apr 2009.

Submit your article to this journal $[\pi$

Џ Article views: 2

Q View related articles $\widetilde{ }$ 
tain-formation. I have nothing to say on this thesis, but I wish to draw attention to what I conceive to be a mistake in his view of Appalachian structure. Great chains, as we all know, consist usually of a granite or metamorphic axis flanked on either side by tilted and often crumpled strata. Now Mr. Reade seems to think that the strata were pushed back and crumpled by the protruded axis. The Appalachian seems inconsistent with this view, but $\mathrm{Mr}$. Reade thinks only seemingly so, because the crumpled strata on the eastern flank have been completely carried away by erosion.

Now American geologists believe they have good reason to think that the metamorphic region of the Appalachian does not belong to the Appalachian chain proper at all, but existed as land long before the Appalachian was born, viz. at the very beginning of the Paimozoic Era. The evidence of this is, that the very lowest Paliozoics lie everywhere unconformatly on the eroded edges of the crumpled Archæan, and even the outlines of the old Cambrian shore-line can be traced. The Appalachian was not formed until the end of the Palæozoic.

Perhaps it may not be amiss to call attention also to the structure of the coast-range of California. It is strongly crumpled, with at least five anticlines and corresponding synclines*, and yet in many places no sign of a granite or metamorphic axis.

Berkeley, Cal., Very truly, March 29, 1888.

\section{ON THE ACTION OF LIGHT ON THE ELECTRICAL CONDUCTIVITY OF THE HALOID SALTS OF SLLVER. BY SVANTE ARRHENIUS.}

Two parallel silver wires were coiled, at a distance of 2 millim., about a rectangular glass plate $(4 \times 5$ centim.), then painted with an ammoniacal solution of chloride or bromide of silver, and slowly heated until the water and ammonia had evaporated, so as to form a thin skin of chloride or of bromide of silver. The plate was covered with a screen with a slit 1 centim. in breadth, and thereupon placed in various parts of a spectrum $7 \cdot 2$ centim. in length. The silver wires were introduced into the circuit of a battery of 40 Clark's elements, in which was a very sensitive reflectinggalvanometer ( 1 div. $=7 \times 10^{-11} \mathrm{amp}$.). Without illumination the galvanometer gave a constant deflection. With illumination this was greater, but returned to its former value on darkeniug. When the width of the slit which produced the spectrum was respectively $0 \cdot 60,0 \cdot 473$, and $0 \cdot 24$ centim. in breadth, the action of the light for each part of the spectrum was proportional to the intensity of the light. For the varions colours, the action increased from the red to the line G, first of all slowly, then move rapidly, and sank then to the ultra-violet in the reverse direction. The action is thus not

* Amer. Journ. Science, vol. ii. p. 297 (1876). 
due to the heating, but corresponds to the strength of the photochemical action. According to the author, the velocity of the action of two bodies, whose specitic electrical conductivities are $\lambda$ and $\lambda_{1}$, is proportional to the product $\lambda_{1} \lambda_{1}$; and thus in a mixture of gelatine and chloride of silver the action must be nearly proportional to the conductivity of chloride of silver, since $\lambda$ must be regarded as tolerably constant for the former. If sensitisers are present, $\lambda$, the conductivity of the sensitiser, is variable, and a maximum is obtained for the colour which exerts an influence, and which corresponds to a sharp absorption-band, together with the other maximum without sensitiser.-Wiener Berichte, vol, xevi. p. 831 (1887); Beiblätter der Physik, No. 2 (1888).

\section{GLACIAL MOTION.}

\section{To the Editors of the Philosophical Mragazine and Journal.}

\section{Gentlemer,}

In your issue of Febuary last (p. 156) Mr. Deeley brings forward what he thinks is a new theory of Glacial Motion ; but, if I am not greatly mistaken, it does not differ essentially from that of James Thomson. In regard to this theory, in 1882 I wrote as follows *:"Some time ago James Thomson brought forward a theory which deserves far more attention than it has yet received. Thomson shows that the fusing-point of ice is lowered by pressure, and therefore that ice at or near its freezing-point (as is the fact in glaciers) is promptly melted by pressure. Now it is obvious that in the differential motion of a glacier, whatever point, at any moment, receives the greatest stress of pressure must melt and give way, and, the stress being relieved, must immediately again refreeze. Meanwhile, by change of relative position of parts, the stress is transferred to some other point which in its turn melts, gives way, and is refrozen ; and again transfers its stress to still another point, and so on. If we compare this theory with Tyndall's, in both cases the ice gives way at the point of greatest stress : in the one case the stress is a stress of tension, in the other of pressure; in the one case the giving way is by fracture, in the other by melting. The differential motion in the one case is by fracture, change of position and regelation; in the other by melting, change of position and regelation."

These of course are not Thomson's words, but only a condensed statement of my own of the view I got from studying Thomson.

Very respectfully,

Berkeley, Cal., JOSEPH LECONTE.

March 28, 1888.

* 'Elements of Geology,' p. 603 . 